\title{
Fecundity, growth rate and survivorship at the interface between two contiguous genetically distinct groups of Semibalanus balanoides
}

\author{
Anik Brind'Amour ${ }^{1}$, Edwin Bourget ${ }^{2, *}$, Réjean Tremblay ${ }^{3}$ \\ ${ }^{1}$ Groupe de Recherche Interuniversitaire en Limnologie (GRIL), Département de sciences biologiques, Université de Montréal. \\ CP 6128, succursale Centre-ville, Montréal, Québec H3C 3J7, Canada \\ ${ }^{2}$ Groupe Interuniversitaire de recherches océanographiques du Québec (GIROQ), Département de biologie, \\ Université Laval, Ste-Foy, Québec G1K 7P4, Canada \\ ${ }^{3}$ Centre aquacole marin de Grande-Rivière (CAMGR), Ministère de l'agriculture, des pêcheries et de l'alimentation du \\ Québec, 6 du Parc, Grande-Rivière, Québec G0C 1V0, Canada
}

\begin{abstract}
On the western coast of the Atlantic, according to the literature, 2 distinct groups of Semibalanus balanoides occur with a distinct interface near the Miramichi Estuary, New Brunswick, in the Gulf of St. Lawrence. On each side of this interface, the groups are characterized by clinal variations for MPI (mannose-6-phosphate isomerase) and GPI (glucose-6-phosphate isomerase). The present study was carried out to determine whether selection occurs at this interface, to establish how early in the sessile life period it occurs and to examine the selecting forces involved. Reciprocal transplant experiments of newly settled individuals to both sides of the interface were carried out. No significant differences specifically linked to source or destination were observed in growth or fecundity for the 2 groups at the sites studied for either control or transplanted individuals. However, differences in survival were observed; individuals transplanted south of the estuary showed lower survival than individuals transplanted north. An allozyme analysis of barnacle survivors for MPI and GPI, 2 alleles whose frequencies are known to vary abruptly in this region, indicated a change of allele frequency in transplanted individuals. The transplants' allele frequencies came to resemble those of adults from target sites, while no change occurred in transplanted individuals at control sites. Taken together with previous results, our study suggests that selection occurs very early in the newly settled individuals (spat).
\end{abstract}

KEY WORDS: Semibalanus $\cdot$ Genetics $\cdot$ Selection $\cdot$ Fecundity $\cdot$ Growth rate $\cdot$ Survival

\section{INTRODUCTION}

In many temperate and tropical benthic marine invertebrates, planktonic larvae represent the main means of dissemination. Given sufficient food and an absence of acute predation, the duration of the pelagic larval stage and the current speed are thought to define both the potential distance of dispersion of those species and the gene flow (Scheltema 1986). Theoretically,

\footnotetext{
${ }^{*}$ Corresponding author. Present address: Vice-recteur à la recherche, Université de Sherbrooke, Sherbrooke J1R 2R1, Canada. E-mail: edwin.bourget@rectorat.usherb.ca
}

there should be an inverse relationship between planktonic larval duration and dispersal and the likelihood of genetic differentiation between adjacent populations (Crisp 1978). Although for some groups of species this relationship seems to hold (seastars: Nishida \& Lucas 1988, Williams \& Benzie 1993), for others it does not (mussels: Koehn et al. 1980, Hedgecock 1986, Johannesson et al. 1990, Quesada et al. 1995; scallops: Parsons 1996). Other causes, beside genetic drift, could explain the latter situations: (1) restriction of gene flow, including immigrant infertility (Burton 1983), nonrandom mating (Johannesson et al. 1993), larval retention or directional dispersion mechanisms (Dando \& Southward 1981, Mitton et al. 1989, Parsons 1996), larval 
behavior (Burton \& Feldman 1982), or (2) natural selection (Koehn et al. 1980, Johannesson et al. 1990, Brown \& Chapman 1991, McDonald 1991, Duggins et al. 1995, Schmidt \& Rand 1999).

Semibalanus balanoides, the common boreoarctic intertidal barnacle, is found on both sides of the Atlantic and on the western Pacific coast of America (Bourget et al. 1989). Along the western Atlantic coast, it extends from Greenland and the Canadian Arctic to North Carolina (Barnes \& Barnes 1976). S. balanoides is presumed an obligate cross-fertilizing hermaphrodite (Barnes 1957) and in the eastern Gulf of St. Lawrence, fertilization occurs in October. Fertilized eggs are incubated in the mantle cavity over winter and are hatched the following spring. Planktonic development includes larval stages: 6 nauplii stages and 1 cyprid stage (Bousfield 1954).

Genetic studies of Semibalanus balanoides along the western Atlantic coast of North America and Gulf of St. Lawrence indicate there are 2 distinct populations (Bourget et al. 1989). From observations at a limited number of stations, Bourget et al. (1989) suggested that barnacles from the western Gulf were larger and their post-settlement growth rate was higher than barnacles from the Atlantic shores. Moreover, western Gulf cypris larvae (Capucins, Québec) behaved differently from Atlantic larvae (St. Andrews, New Brunswick), in such a way that the former settled preferentially (>95\%) in crevices and the latter settled mainly on exposed surfaces (see Bergeron \& Bourget 1986, Chabot \& Bourget 1988). The allelic frequencies at 2 enzyme loci, mannose-phosphate isomerase-2 $\left(M^{*} I^{*} 2\right)$ and glucose-phosphate isomerase-2 $\left(G P{ }^{*} 2\right)$ differed between the 2 populations; the western Gulf individuals showing higher frequencies for $M P I^{*} 2$ and lower frequencies for $G P I^{*} 2$ than the Atlantic population (Martel 1990). In a subsequent genetic study of $S$. balanoides at 19 sites along the Atlantic coast of North America from Greenland and Baffin Island, the Gulf of St. Lawrence, the Atlantic coast of Nova Scotia and New Brunswick (Canada), regular clinal variations at those same 2 loci (mannose-6-phosphate isomerase, $M P I$ and glucose-6-phosphate isomerase, GPI) for these populations were observed with a distinct genetic interface located in the vicinity of the Miramichi estuary, New Brunswick (Holm \& Bourget 1994).

In this study, we examine selection and the effect of geography on the newly settled individuals (spat), as well as the selective forces, by means of reciprocal transplantations between the 2 populations of Semibalanus balanoides in the vicinity of Miramichi estuary. Specifically, we compare fecundity in local populations, survivorship and growth rate in reciprocally transplanted barnacles from north and south of the Miramichi Estuary and controls. Electrophoretic allo- zyme analyses of survivors were carried out in order to determine genotype. This approach was better than others, as reciprocal transplant experiments have been shown to be useful to highlight the causes of genetic differentiation among populations (Crisp 1964, 1968, Johannesson et al. 1990, Kautsky et al. 1990, Bertness et al. 1991). Larval dispersion and hydrographic patterns within the Miramichi region were simultaneously examined in another study (Drouin et al. 2002 this issue). The gene nomenclature for protein-coding loci follows the recommendations of Shaklee et al. (1990).

\section{MATERIALS AND METHODS}

Study site. The experiments were conducted in the southeastern part of the Gulf of St. Lawrence near the Miramichi Estuary (Fig. 1), during the spring through autumn of 1998. The Miramichi Estuary is one of the largest estuaries in Atlantic Canada covering an area of $300 \mathrm{~km}^{2}$ and a drainage basin area of $14000 \mathrm{~km}^{2}$. Tidal amplitudes in the study area range from approximately 0.5 to $1.4 \mathrm{~m}$ (Locke \& Courtenay 1996).

The shores in the region of study are dominated by over $200 \mathrm{~km}$ of sandy beaches, with at least $100 \mathrm{~km}$ on either side of the Miramichi river mouth. Rocky outcrops are only sproradically present, and throughout the whole region hard substrata occurs primarily in the form of man-made jetties and quays. Indeed, hard substrata is so scarce that sampling sites for Semibalanus balanoides were difficult to find.

Transplant experiments. To examine the extent to which any barnacle population differences in fecundity, growth and survival might be environmentally induced (non-genetic variation) or inherited (genetic variation), we used reciprocal transplantations. Two series of transplantations were carried out based on published genetic results (Holm \& Bourget 1994). A first set of transplantations (Expt 1) started $5 \mathrm{~d}$ after beginning settlement (all were carried out on 29 May 1998) and ended in mid-November the same year. Barnacles from Cap-Lumière, situated south of the Miramichi estuary (one origin), were transplanted to 4 different destinations, 2 of them located north of the estuary (Burnt Church and Val-Comeau) and 2 located south of the estuary (Pointe-Sapin and Cap-Lumière; Fig. 1). A second set of transplantations (Expt 2) started 48 d (July 11) after settlement (mid-May 1998), and ended in mid-November 1998. Barnacles from Le Goulet (situated north of the Miramichi estuary), CapLumière and Saint-Edouard (both situated south of the estuary) were transplanted to Burnt Church and ValComeau (both situated north of the estuary) as well as Pointe-Sapin and Cap-Lumière (both situated south of 
the estuary; Fig. 1). The reciprocal transplant experiments could not be carried out during the course of this work because initially settlement occurred only south of the Miramichi. There were no significant differences in initial size (rostro-carinal diameter) among destinations from any origins (Le Goulet: $F=2.371, \mathrm{df}=3$, $\mathrm{p}>0.112$; Cap-Lumière: $F=2.389, \mathrm{df}=3, \mathrm{p}>0.074$; Saint-Edouard: $F=2.079, \mathrm{df}=4, \mathrm{p}>0.091$ ).

Expt 1. For the first set of transplantations, recently metamorphosed Semibalanus balanoides recruits were collected on 16 cobbles (diameter $=$ ca. $18 \mathrm{~cm}$ ) of similar heterogeneity $(F=1.71, \mathrm{df}=2, \mathrm{p}>0.2492)$, as measured using a carpenter's profiler (2 measurements made at right angles to one another, precision $\pm 1 \mathrm{~mm}$, see Guichard \& Bourget 1998). Settlement lasted about $10 \mathrm{~d}$. Recruits were thinned haphazardly to $<1$ ind. $\mathrm{cm}^{-2}$ in order to avoid competition, and other organisms were also removed from supporting cobbles. Five

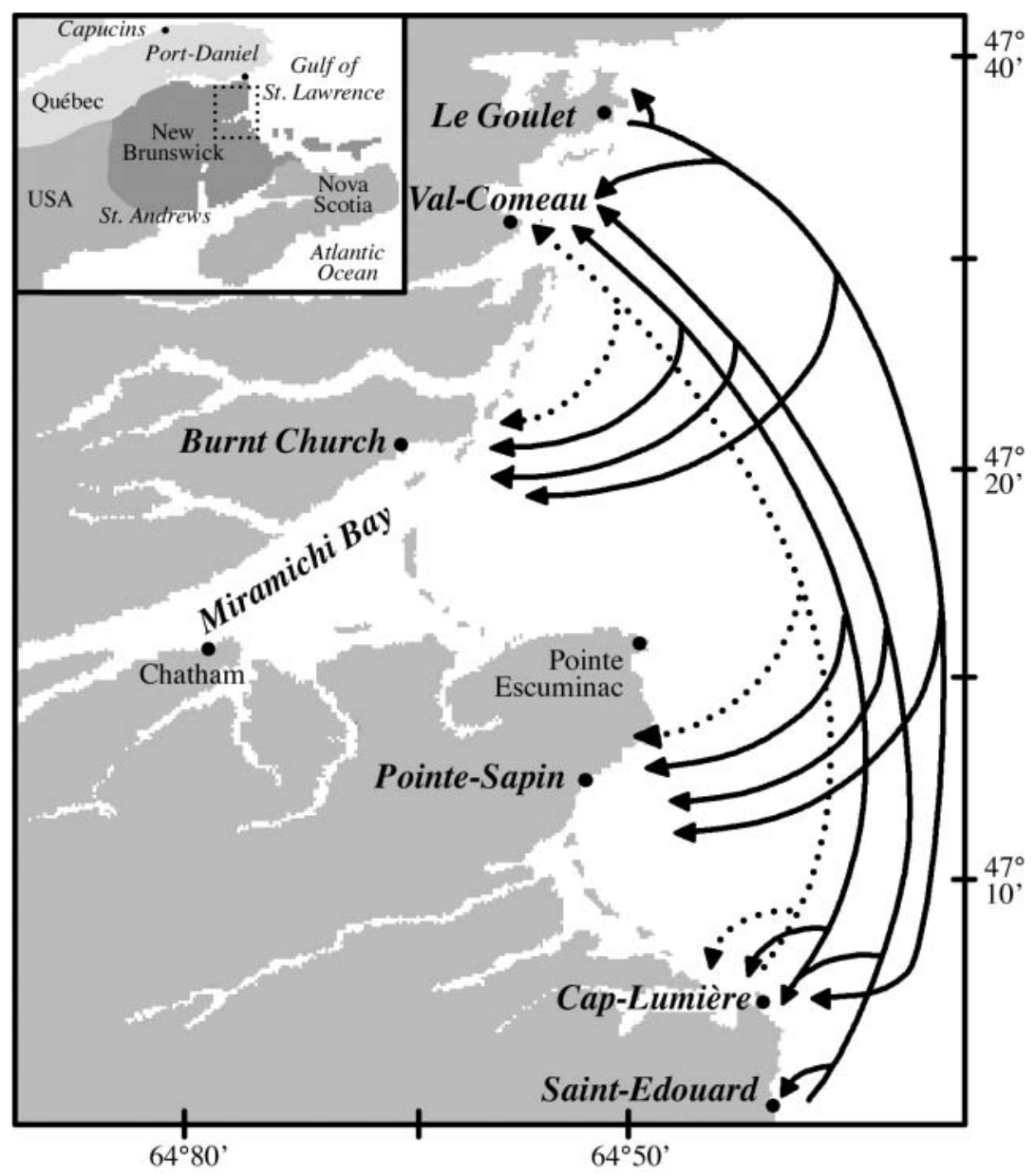

Fig. 1. Sites from which Semibalanus balanoides recruits were sampled for the transplant experiments. Dotted and full lines represent the sites used for the first and the second experiments respectively. Barnacles originated from Cap-Lumière (1 origin) in the first experiment and from Le Goulet, Cap-Lumière and SaintEdouard (3 origins) in the second experiment. Arrows are directed towards the transplant destinations days after settlement had ceased (May 29), cobbles collected at Cap-Lumière, supporting on average $31.2 \pm$ 13.9 spat per cobble (maximum age $=15 \mathrm{~d}$ ), were transplanted to the 4 destinations (Val-Comeau, Burnt Church, Pointe-Sapin and Cap-Lumière). Cobbles were secured to the breakwater rock using Kwik Plug ${ }^{\circledR}$ Lepage (Kingston, Ontario) cement according to their initial orientation and shore level. Transplanted cobbles remained solidly in place at least until Day 220, but some were lost late in autumn and therefore our statistical analyses did not include data from Day 320 (Day = day of the year).

Expt 2. For the second set of transplantations, 42 cobbles (diameter $=$ ca. $22 \mathrm{~cm}$ ) of similar heterogeneity $(F=1.43, \mathrm{df}=1, \mathrm{p}>0.3540)$, colonized with Semibalanus balanoides (average $13.1 \pm 8.8$ individuals per cobble) spats, were used. Recruits were thinned out to $<1$ ind. $\mathrm{cm}^{-2} 48 \mathrm{~d}$ after the beginning of settlement, and 3 cobbles from each origin (Le Goulet, Cap-Lumière and SaintEdouard) were transplanted to 4 destinations (Val-Comeau, Burnt Church, Pointe-Sapin and Cap-Lumière). Control transplantations were also done (3 replicates per origin). Cobbles from different sources were interspersed, placed at the same tidal height and secured to substratum as above.

Growth and survival. Experimental cobbles were photographed first on the day of transplant and then at monthly intervals between May and August, and finally in November 1998. The basal area, as well as rostro-carinal and lateral-lateral basal diameters (precision $= \pm 0.1 \mathrm{~mm}$ ) were monitored using SigmaScan Pro (1995). Since the basal area and the 2 diameter measurements were highly correlated (Spearman $\mathrm{R}^{2}>$ 0.96, $\mathrm{N}=1003, \mathrm{p}<0.0001$ ), only the rostro-carinal diameter was used in the analysis.

Fecundity. To estimate the fecundity of local (non-transplanted) populations north and south of the Miramichi estuary for 1997, we collected 50 individuals randomly immediately prior to larval release (15 to 19 April 1998) at each of the 4 localities (north: Val-Comeau, Burnt Church; south: Pointe-Sapin and Cap-Lumière). We measured the rostro-carinal basal diameter and 
height using vernier calipers (accurate to $0.1 \mathrm{~mm}$ ) and separated the egg masses (containing embryos at that stage) from the soft tissue under the microscope. The egg masses were kept in $20 \%$ formaldehyde. Wet masses of eggs (and embryos) were washed in 3\% ammonium formate and then passed through a $500 \mu \mathrm{m}$ nylon filter prior to being weighed to $\pm 0.1 \mathrm{mg}$. The number of eggs per mg of wet egg tissue was estimated by counting 2000 eggs and weighing these to the nearest $0.1 \mathrm{mg}$. On average, 2000 eggs were observed per $29 \pm 3 \mathrm{mg}$ of egg tissue. Thus, total number of eggs per individual varied from 2455 to 6532 . For reasons of simplicity, results will be presented as mass only. To estimate the fecundity of 1998, individuals were collected immediately after brooding from 14 to 17 November 1998 (Val-Comeau: 10; Burnt Church: 14; Pointe-Sapin: 20; and Cap-Lumière: 13) and egg mass was again determined to the nearest $0.1 \mathrm{mg}$.

To determine if destination of transplanted individuals influenced fecundity, shell measurements and egg mass were determined as described above for transplanted individuals at all the study sites immediately after fertilization in the fall.

Electrophoresis. The somatic tissue of transplanted survivors on Day 320 for both experiments was collected for fecundity analysis and was kept at $-80^{\circ} \mathrm{C}$ for genetic analysis. Saint-Edouard to Val-Comeau, SaintEdouard to Pointe-Sapin and Le Goulet to Le Goulet were not included in the statistical analyses as the number of individuals was too low $<10$ ind. at the end of the experiment) to provide reliable representation. Tissues were homogenized in 50 to $75 \mu \mathrm{l}$ of an allozyme grinding buffer as described by Holm \& Bourget (1994; $50 \mathrm{mM}$ Tris-HCl pH 8.0, $1 \mathrm{mM} \mathrm{MgCl}_{2}$, $1 \mathrm{mM}$ DTT, $50 \% \mathrm{v} / \mathrm{v}$ glycerol). The locus for the MPI enzyme was resolved using $5 \mu \mathrm{l}$ of homogenate, applied to cellulose acetate plates at the cathodal end of the gel and run at $200 \mathrm{~V}$ for 20 to $25 \mathrm{~min}$. The locus for the GPI enzyme was scored after migration on vertical discontinuous polyacrylamide slab gels (Ornstein 1964). Samples were all run with at least one standard known genotype. Enzymes were stained according to Hebert \& Beaton (1989).

Environmental factors. To examine the selective forces that could act on mortality, 3 environmental factors were recorded during the experiments. Temperature and chl a samples (3 replicates) were taken simultaneously $1 \mathrm{~m}$ from the shore, at a depth of $50 \mathrm{~cm}$ on each sampling date at each site. Chl a samples were filtered through a fiber filter $(0.5 \mu \mathrm{m})$ within $1 \mathrm{~h}$ after sampling and were kept frozen until their extraction. They were then analyzed by fluorometry (Turner fluorometer) using Strickland \& Parsons' (1968) methods. Salinity data were measured and were obtained from the study by Drouin et al. (2002).
Statistical analyses. Statistical analyses were carried out either with SAS (SAS 1998) or SPSS (SPSS 1999), and REAP (McElroy et al. 1991) using a significance threshold of 0.05. Assumptions of normality and homoscedasticity were met, at times by transformation of the data. Heterogeneous variance was sometimes observed, but the analysis of variance is relatively robust to unequal variances (Milliken \& Johnson 1992), provided that the larger sample sizes correspond to the populations with the larger variances, which was always the case. Normality was tested using the Shapiro-Wilks statistics (Zar 1984). Residual homoscedasticity was visually verified and confirmed (Montgomery 1991). When a source of variation was significant, a posteriori multiple comparisons (LS means; SAS 1998) were performed. Because of the loss of many cobbles during the study, the duration of the transplantations varied and the analysis of growth and survival were carried out on data until Day 220 in both experiments.

Growth. The analysis of growth rates of barnacles used in the 2 sets of transplant experiments were done using the Proc Mixed procedure for mixed linear models with a spatial power type and an autoregressive structure with unequal spacing in time (Littell et al. 1998). To compare the growth rates $\left(\mathrm{mm} \mathrm{d}^{-1}\right)$, simple contrasts were done (Montgomery 1991). The growth rates were examined as a function of origin, destination and days, comparing recruits sharing the same origin and transplanted to different destinations to control recruits (origin transplanted to origin). In the second experiment, growth data were log transformed to meet the normality and heteroscedasticity assumptions. The analysis was carried out as for the first transplant experiment.

Survival. Survival analysis was carried out using Lifetest procedure (SAS 1998) based on Wilcoxon's Log-Rank statistics for the 2 experiments separately. Comparisons of the shape of the survival curves were carried out 2 at a time, taking into account origin and destination.

Fecundity. Natural fecundity of the 2 populations for each site for the years 1997 (collection in April 1998) and 1998 was examined using an analysis of covariance. Basal diameter was used as the covariable, as it was correlated $\left(R^{2}=0.34, n=102, p<0.0001\right)$ with the egg mass. Data were log transformed to meet normality and homoscedasticity assumptions.

To compare the fecundity of transplanted recruits, an analysis of covariance was done taking into account origin and destination. The 2 experiments were also analyzed separately. Because egg mass was correlated with the basal area of barnacles $\left(\mathrm{R}^{2}=0.44, \mathrm{n}=79\right.$, $\mathrm{p}<0.0001)$, the basal area was used as a covariable in the analyses. 
Table 1. Semibalanus balanoides. Growth analysis using Proc Mixed procedure (Littell et al. 1998). Fixed factors and random factors are shown in the table. Date is included as a covariable since time intervals between sampling periods were unequal. ${ }^{*}: \mathrm{p}<0.0001$. NDF: numerator degree of freedom; DDF: denominator degree of freedom; SP: spatial power. Estimates are the random effects representing the estimated deviation.

\begin{tabular}{|c|c|c|c|c|c|c|}
\hline \multicolumn{4}{|c|}{ Fixed factors } & \multicolumn{3}{|c|}{ Random factors } \\
\hline \multicolumn{2}{|c|}{ Source of variation } & $\mathrm{DDF}$ & $F$ & $\begin{array}{l}\text { Covariance } \\
\text { parameter }\end{array}$ & Subjects & Estimates \\
\hline \multicolumn{7}{|c|}{ a) Barnacles transplanted $5 \mathrm{~d}$ after settlement } \\
\hline & Destination & 203 & $474.88^{*}$ & $\mathrm{SP}(\mathrm{POW})$ & \multirow[t]{2}{*}{ Barnacle (Destination $\times$ Cobble) } & 0.9832 \\
\hline & Date $\times$ Destination & 690 & $479.72^{*}$ & Residual & & 1.5354 \\
\hline \multicolumn{7}{|c|}{ b) Barnacles transplanted $48 \mathrm{~d}$ after settlement } \\
\hline & Origin $\times$ Destination & 142 & $15.78^{*}$ & $\mathrm{SP}(\mathrm{POW})$ & \multirow[t]{2}{*}{ Barnacle $($ Origin $\times$ Destination $\times$ Cobble $)$} & 0.9959 \\
\hline & Date $\times$ Origin $\times$ Destination 13 & 142 & $16.63^{*}$ & Residual & & 0.0528 \\
\hline
\end{tabular}

Genetic analysis. Allelic frequencies were calculated for each locus using the BIOSYS-1 program of Swofford \& Selander (1989). Genotype frequencies were not presented because the sample size was too small and no reliable representation could be expected. Comparisons of allelic frequencies for each locus within and among origins were carried out with $\chi^{2}$ Monte-Carlo simulations (Roff \& Bentzen 1989) of the REAP program (McElroy et al. 1991) using sequential Bonferroni corrections. Missing data on Day 320 were primarily due to the incapacity of reaching the cobbles because of ice covering the substrata.

Environmental factors. The relationship between the 3 environmental factors (temperature, chl $a$ and salinity, see above) and survival of young recruits was

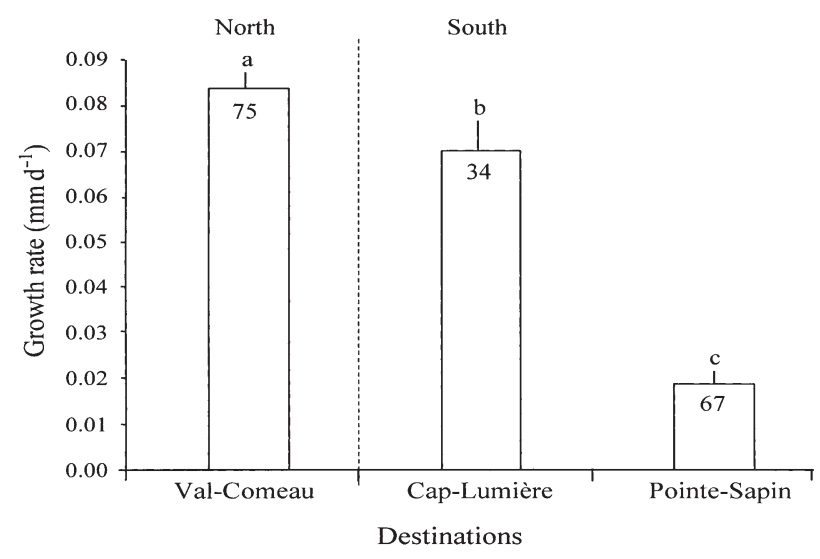

Fig. 2. Semibalanus balanoides. Growth rate $\left(\mathrm{mm} \mathrm{d}^{-1}\right)$ of recruits transplanted from Cap-Lumière $5 \mathrm{~d}$ after settlement. Histogram bars represent the slopes of the growth curves, calculated using the Proc Mixed procedure (Littell 1998) on individuals from 4 cobble replicates that initially held an average of $31.2 \pm 13.9$ solitary individuals. Results for Burnt Church destination are not shown, as only 2 sampling dates were obtained. These were not included in the statistical analysis. Numbers inside histogram bars represent sample sizes. Values with dissimilar letters differ significantly. Vertical bars indicate standard errors examined by a multiple regression analysis using SPSS package. The dependent variable was survival (logtransformed) and the independent variables were temperature, salinity and chl a concentration.

\section{RESULTS}

\section{Growth}

Expt 1

Recruits transplanted 5 d after settlement (from CapLumière to Val-Comeau, Burnt Church, Pointe-Sapin and Cap-Lumière), differed in their growth rates according to local destination. Recruits transplanted north of the Miramichi showed slightly better growth than the recruits transplanted south of the Miramichi (Table 1a). Recruits transplanted to Val-Comeau grew slightly faster than the recruits of Cap-Lumière, and both Val-Comeau and Cap-Lumière individuals grew 3 to 4 times faster than the recruits transplanted to Pointe-Sapin (Fig. 2).

\section{Expt 2}

The July to November growth rates of recruits transplanted 48 d after settlement (from Le Goulet, CapLumière and Saint-Edouard to Val-Comeau, Burnt Church, Pointe-Sapin and Cap-Lumière) differed significantly among destinations but the site to site variations suggest these variations are not linked to the regions north or south of the Miramichi (Table 1b). Recruits from Cap-Lumière transplanted to Burnt Church had a faster growth than the ones transplanted to Pointe-Sapin. No differences were found between recruits originating from Saint-Edouard and from Le Goulet transplanted to Val-Comeau, Burnt Church, Pointe-Sapin and Cap-Lumière (Fig. 3). 


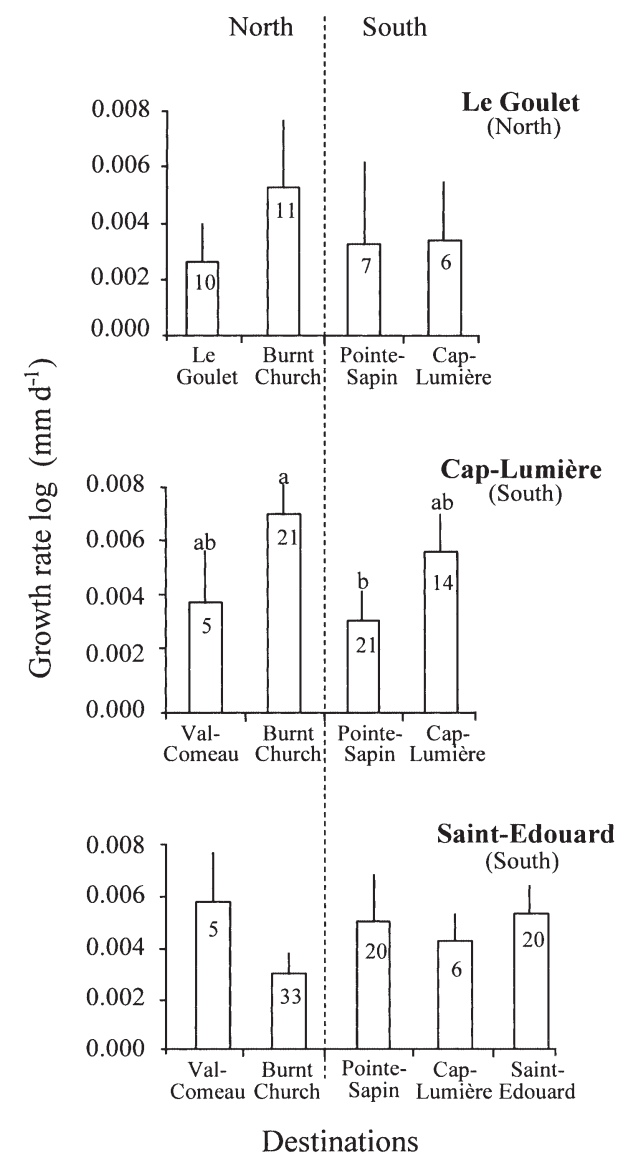

Fig. 3. Semibalanus balanoides. Growth rate of recruits transplanted $48 \mathrm{~d}$ after settlement. The origin is indicated in bold characters above each figure. Histogram bars represent the slopes of the growth curves calculated using the Proc Mixed procedure (Littell 1998) on individuals from 3 cobble replicates that initially held an average of $13.1 \pm 8.8$ solitary individuals. Vertical bars indicate standard errors. Significant differences are shown by dissimilar letters. Data were log transformed to meet assumptions of normality and homoscedasticity

\section{Survival}

Transplanted individuals showed different survivals according to their destination. Recruits transplanted north of the Miramichi had a much higher survival than recruits transplanted south of the Miramichi.

\section{Expt 1}

For the recruits transplanted from Cap-Lumière, survival curves (Fig. 4) varied significantly among destinations (Gehan's Wilcoxon $W=80.67$, df $=3$, p < 0.0001). At the end of the experiment, the survival varied from $60 \%$ (recruits transplanted to Val-Comeau) to $9 \%$ (recruits transplanted to Cap-Lumière).

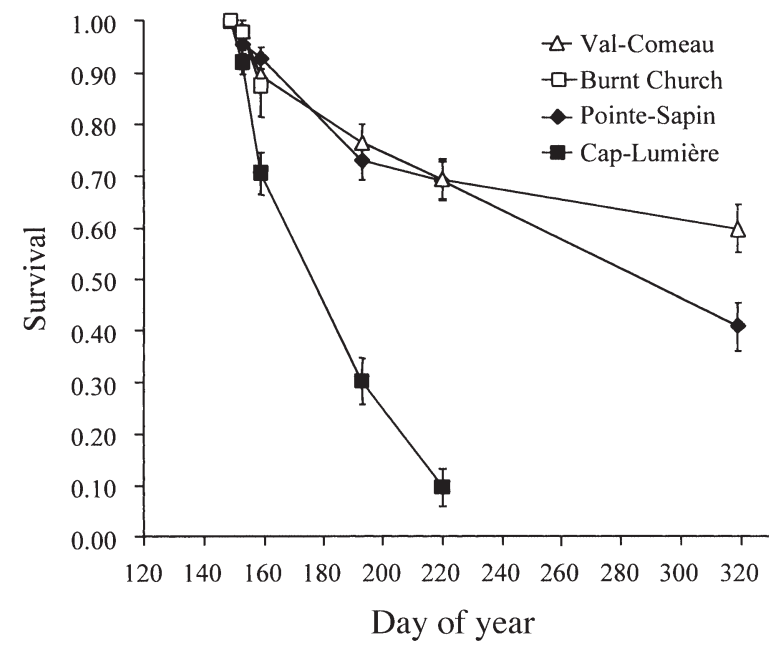

Fig. 4. Semibalanus balanoides. Survivorship of recruits transplanted from Cap-Lumière to different destinations $5 \mathrm{~d}$ after settlement. Data from each destination were collected on individuals located on 4 cobbles that initially supported on average $31.2 \pm 13.9$ solitary individuals each. Burnt Church cobbles were lost during the experiment on Day 159. Vertical bars indicate the standard errors

\section{Expt 2}

The slopes (average) of the 13 survival curves (Fig. 5) for the recruits transplanted $48 \mathrm{~d}$ after settlement differed significantly ( $W=60.97$, df $=12, \mathrm{p}<0.0001$ ). During the experiment, survival varied from 100\% (recruits transplanted from Le Goulet to Pointe-Sapin) to $32 \%$ (recruits transplanted from Saint-Edouard to Cap-Lumière). The recruits from Le Goulet and CapLumière showed no survival differences with the recruits transplanted to other sites. However, survival of individuals transplanted from Saint-Edouard to Pointe-Sapin and Cap-Lumière was lower than the transplant controls (Saint-Edouard to Saint-Edouard) and transplants to the northern sites (Val-Comeau and Burnt Church). While survival of the southern site transplants was $20 \%$ lower than the transplants to the northern sites, this difference was not statistically significant (see Fig. 5).

When survival is examined according to destination but independently of origin, recruits transplanted to the north destinations (Val-Comeau and Burnt Church) showed a much better survival rate than those transplanted to the south destinations (Cap-Lumière and Pointe-Sapin; $W=23.28$, df = 3, p < 0.0001; Fig. 6).

\section{Fecundity}

Fecundity results reveal the brooding variability among years and sites. The analysis showed that bar- 

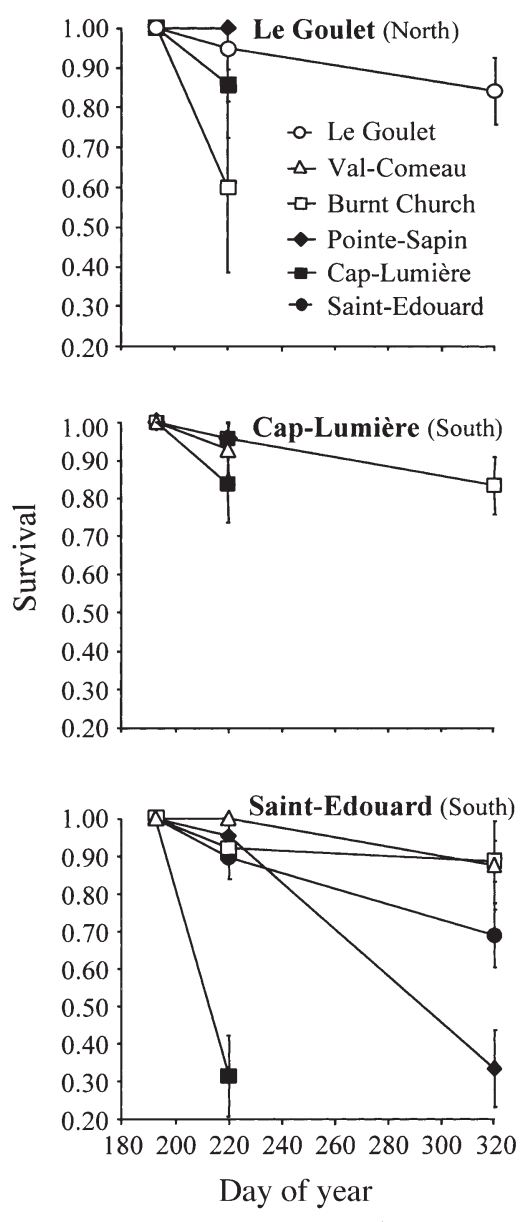

Fig. 5. Semibalanus balanoides. Survivorship of recruits transplanted from Le Goulet, Cap-Lumière and Saint-Edouard $48 \mathrm{~d}$ after settlement. Data from each destination were obtained from 3 replicates that initially supported on average $13.1 \pm 8.8$ solitary recruits. Vertical bars indicate standard errors. Empty symbols represent sites located west and full symbols represent sites located east of the Miramichi estuary

nacles fertilized in autumn 1997 (collected in April 1998) contained more eggs than barnacles fertilized in autumn 1998, with all sites pooled together (Table 2). No significant interactions (site $\times$ year) were observed.

Table 2. Semibalanus balanoides. Analysis of variance showing the effect of site, year and their interaction on egg masses $(\mu \mathrm{g})$. Natural logarithm was used to meet the ANOVA assumptions. ${ }^{*} \mathrm{p}<0.05,{ }^{* *} \mathrm{p}<0.0001$, and ns: $\mathrm{p}>0.05$

\begin{tabular}{|lrcc|}
\hline Source of variation & df & MS & $F$ \\
\hline Site & 3 & 1.6381 & $3.02^{*}$ \\
Year & 1 & 9.8281 & $18.10^{* *}$ \\
Site $\times$ Year & 3 & 0.9497 & $1.75 \mathrm{~ns}$ \\
Error & 92 & 0.5430 & \\
Corrected total & 100 & & \\
\hline
\end{tabular}

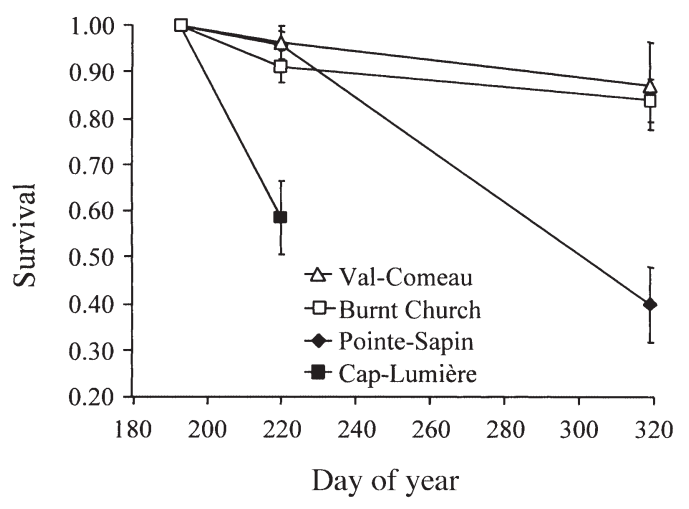

Fig. 6. Survivorship of Semibalanus balanoides recruits transplanted $48 \mathrm{~d}$ after settlement (all origins pooled) according to destination. Data from each destination were obtained from 9 cobbles that initially supported on average $12.8 \pm 9.2$ solitary recruits. Vertical bars indicate standard errors. Survivorship at the west destinations (Val-Comeau and Burnt Church) differed significantly from that of the east destinations (PointeSapin and Cap-Lumière)

Barnacles located at Pointe-Sapin possessed significantly fewer eggs than barnacles located at ValComeau and Cap-Lumière.

No difference in fecundity could be linked to destination (north or south of the Miramichi). In our study, nearly all $(98 \%, \mathrm{n}=112)$ transplanted recruits sampled at the end of the experiment contained eggs. The egg wet mass of the transplanted recruits showed no significant difference between sites either for recruits that were transplanted $5 \mathrm{~d}$ after settlement $(F=0.24, \mathrm{n}=35$, $\mathrm{df}=1, \mathrm{p}>0.6249$ ) or recruits transplanted $48 \mathrm{~d}$ after settlement $(F=1.67, \mathrm{n}=75, \mathrm{df}=5, \mathrm{p}>0.1535)$.

\section{Genetic analysis}

Data available for the genetic analysis came from barnacles sampled south of the estuary, either from Cap-Lumière or Saint-Edouard and which were transplanted to the south (Saint-Edouard) or north (Burnt Church or Val-Comeau) of the estuary. Allelic frequencies, given in Tables $3 \& 4$, show the coefficients for heterozygote deficiency or excess. Two common MPI and GPI alleles were observed ( 2 and 3 ) based on their distance from the origin on the gel. All but one of the samples analyzed (Saint-Edouard to Burnt Church) were in Hardy-Weinberg equilibrium and no linkage disequilibrium between loci was detected. Although not significant, recruits transplanted to the south (Saint-Edouard transplanted to Saint-Edouard), had higher $M P I^{*} 2$ frequencies and lower $G P I^{*} 2$ frequencies, than recruits transplanted to the north (ValComeau and Burnt Church), which showed higher $G P I^{*} 2$ frequencies and lower $M P I^{*} 2$ frequencies, sug- 
Table 3. Semibalanus balanoides. Allelic frequencies at 2 loci for the survivors of Val-Comeau (V-C), Burnt Church (BC), Cap-Lumière (C-L) and Saint-Edouard (S-E). Numbers in parentheses represent sample size. Bold letters show the statistical results obtained from $\chi^{2}$ Monte-Carlo simulations adjusted with the Bonferroni correction. Significant differences are shown by different letters. ${ }^{a}$ Data from the first experiment

\begin{tabular}{|ccccc|}
\hline & \multicolumn{5}{c|}{ Destinations } & - South - \\
\cline { 2 - 5 } Locus/ & \multicolumn{5}{c|}{$\begin{array}{c}\text { North } \\
\text { Allele }\end{array}$} & $\begin{array}{c}\text { C-L to V-C } \\
(33)^{\mathrm{a}}\end{array}$ & $\begin{array}{c}\text { C-L to BC } \\
(20)\end{array}$ & $\begin{array}{c}\text { S-E to BC } \\
(26)\end{array}$ & $\begin{array}{c}\text { S-E to S-E } \\
(13)\end{array}$ \\
\hline$\frac{M P I}{1}^{*}$ & $\mathbf{a}$ & $\mathbf{a}$ & $\mathbf{a}$ & $\mathbf{a}$ \\
2 & 0.000 & 0.000 & 0.000 & 0.038 \\
3 & 0.561 & 0.550 & 0.462 & 0.615 \\
$\underline{G P I}_{1}^{*}$ & 0.439 & 0.450 & 0.538 & 0.346 \\
2 & $\mathbf{a}$ & $\mathbf{a}$ & $\mathbf{a}$ & $\mathbf{a}$ \\
3 & 0.019 & 0.000 & 0.025 & 0.038 \\
& 0.630 & 0.735 & 0.700 & 0.500 \\
& 0.352 & 0.265 & 0.275 & 0.462 \\
\hline
\end{tabular}

Table 4. Semibalanus balanoides. Coefficients for heterozygote at 2 loci for the survivors of Val-Comeau (V-C), Burnt Church (BC), Cap-Lumière (C-L) and Saint-Edouard (S-E). Numbers in parentheses represent sample size. $H_{\mathrm{o}}$ : observed heterozygotes, $H_{\mathrm{e}}$ : expected heterozygotes, D: deficiency or excess. ${ }^{2}$ Data from the first experiment

\begin{tabular}{|ccccc|}
\hline & \multicolumn{5}{c|}{ Destinations } & - South - \\
\cline { 2 - 5 } Locus & $\begin{array}{c}\text { C-L to V-C } \\
(33)^{\mathrm{a}}\end{array}$ & $\begin{array}{c}\text { C-L to BC } \\
(20)\end{array}$ & $\begin{array}{c}\text { S-E to BC } \\
(26)\end{array}$ & $\begin{array}{c}\text { S-E to S-E } \\
(13)\end{array}$ \\
\hline$\underline{M P I}$ & & & & \\
\hline$H_{\mathrm{o}}$ & 15 & 6 & 4 & 5 \\
$H_{\mathrm{e}}$ & 16.508 & 10.154 & 13.176 & 6.760 \\
$\mathrm{D}$ & -0.091 & -0.409 & -0.696 & -0.260 \\
$\frac{G P I}{H_{\mathrm{o}}}$ & 15 & 5 & 6 & 7 \\
$H_{\mathrm{e}}$ & 13.189 & 6.818 & 8.897 & 7.240 \\
$\mathrm{D}$ & 0.137 & -0.267 & -0.326 & -0.033 \\
\hline
\end{tabular}

gesting a change in the gene frequency only a few months after transplantation. The new frequencies (after transplantation: exclusively for the GPI*2) are consistent with the genotype frequencies of Semibalanus balanoides located on either side of the Miramichi estuary observed by Holm \& Bourget (1994), either for the recruits or the adults (Fig. 7). In short, 4 mo after transplantations on both sides of the Miramichi, the barnacles located on either sides showed frequencies similar to those of natural populations. Estimates of $N_{\text {em }}$ (effective number of migrants per generation) between north and south populations were calculated using the following formula: $1 / 4\left[\left(1-F_{S t}\right) / F_{S t} t\right.$, where $F_{S t}$ is the inbreeding coefficient. Results indicated an $N_{\text {em }}$ of 15.38 for the $M P I$ and of 7.81 for the GPI.

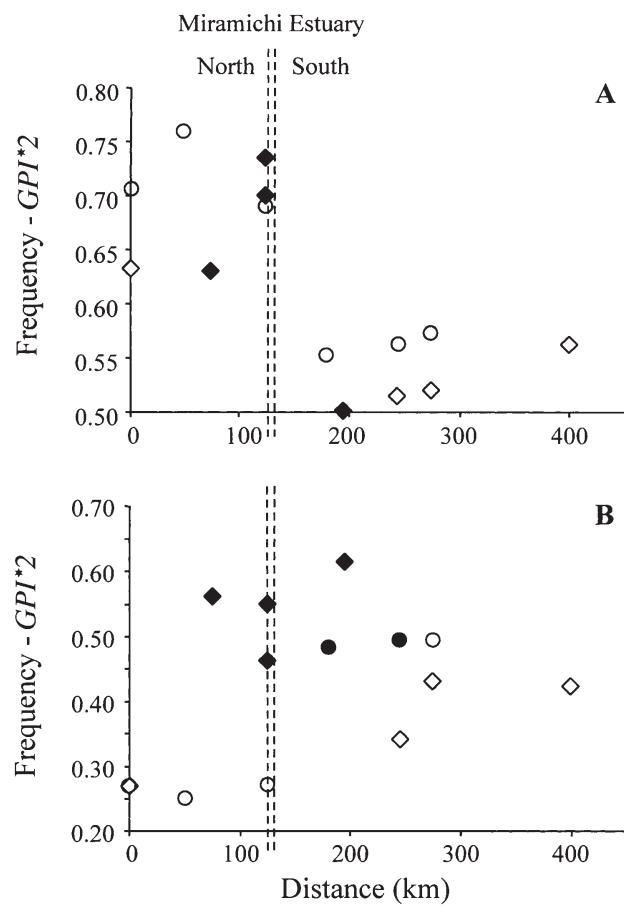

Fig. 7. Semibalanus balanoides. Change in the frequency of (A) $G P I^{*} 2$ and (B) $M P I^{*} 2$ with distance, starting from PortDaniel (Gaspé coast: Fig.1) at 0 km, for transplanted barnacles from our study (filled symbols) and from Holm \& Bourget (1994; empty symbols) study for recruits (circles) and for adults (diamonds). Distances were estimated from 1:500 000 scale maps as straight line distance between sites

\section{Environmental factors}

Monthly mean temperature and salinity were highly correlated (Pearson $\mathrm{r}^{2}>0.893, \mathrm{n}=15, \mathrm{p}<0.0001$ ), while chl a was not correlated to other environmental variables. Although none of the relationships between environmental factors and growth and survival were significant at $\mathrm{p}<0.05$, the equation relating survival to average salinity (Survival $=0.026-0.752 \times$ salinity) was close to being significant $(F=4.145, \mathrm{n}=15, \mathrm{p}=$ 0.064 ) and accounted for $26 \%$ of the variance in survival. This low level of significance may be linked to the small sample size.

\section{DISCUSSION}

Our study was intended to determine whether differential selection occurred between the 2 populations of Semibalanus balanoides (south and north) of the Miramichi estuary. While the results show similarity in growth rate and fecundity among transplanted populations, there were significant survival differences according to destination but no significant allele frequency 
variations after transplantation $\left(M P I^{*}\right.$ and $\left.G P I^{*}\right)$. However the $G P I^{*}$ frequencies of transplanted populations came to resemble those reported for juvenile and adult populations by Holm \& Bourget (1994) for the locality of transplantation.

\section{Physical and biological barriers}

Restriction of gene flow for species with high dispersal capacities could result either from physical (Quesada et al. 1995, Parsons 1996) or biological barriers (Benzie et al. 1992, Ford \& Mitton 1993) to gene flow, or from natural selection (Koehn et al. 1980, Schmidt \& Rand 1999). Known circulation patterns in the southern Gulf of St. Lawrence and larval distribution patterns (Drouin et al. 2002) suggest passive dispersion of the Semibalanus balanoides larvae from north to south of the Miramichi estuary (Lauzier 1965, Koutitonsky \& Budgen 1991) and substantial gene flow between the 2 populations. Another study conducted in our laboratory (Dufresne et al. unpubl.) on microsatellites of adults of Semibalanus balanoides, also confirms extensive gene flow between Gulf populations north and south of Semibalanus balanoides. Furthermore, our estimates of $N_{\mathrm{em}}$ between north and south populations for the 2 loci studied (MPI* and $\left.G P I^{*}\right)$ indicate substantial gene flow, with values $\left(M P I^{*}\right.$ : 15.38 ; GPI*: 7.81; both loci: 10.62) sufficiently high to infer larval mixing among Gulf barnacle populations in the vicinity of the Miramichi estuary.

For invertebrates with planktonic larvae, biological factors that may act on gene flow include food supply, predators and larval behavior (Burton 1983). The biological response variables measured in settled individuals (growth, survival and fecundity) have all been shown to be influenced by environmental factors in barnacles (see Bertness et al. 1991, Minchinton \& Scheibling 1993). They can, however, also be significantly influenced by genetic make-up. Our experiment was aimed at determining the extent to which the genetic variations observed could be perceived as influencing other biological response variables. In our study, differences could be observed between growth rates at some destinations, but those differences could not be associated coherently with 1 of the 2 regions studied (south or north of the Miramichi). Although differences were not statistically significant, young recruits seem to have a slightly better growth when transplanted north of the Miramichi (Fig. 2). This difference, however, seemed to diminish in older barnacles (Fig. 3). These results suggest the presence of local factors, possibly salinity (see below), that act on spat transplanted south of the Miramichi. Comparable fecundity among populations suggests no influence of site or genetics on this response variable in the region of study.

Interestingly, $98 \%$ of newly settled recruits from our study were able to breed within the first year of life, which is at odds with earlier observations stating that breeding of Semibalanus balanoides in New Brunswick did not normally commence until the second year of life (Bousfield 1954).

\section{Selection on newly settled spat}

Low survival was observed at Cap-Lumière in both experiments. The substantial differences in survival observed between the first (spat) and the second experiments (individuals up to $48 \mathrm{~d}$ old ) suggest that the crucial period for selection is the early phases shortly after settlement. This is consistent with results of many other studies (see Theisen 1978, Wethey 1984, Schmidt \& Rand 1999). But while numerous studies have shown the high vulnerability of newly settled spat to local conditions (Connell 1961, Wethey 1986, Raimondi 1988, Gosselin \& Qian 1996, 1997, Hunt \& Scheibling 1997, Pechenik et al. 1998), here, the causal factor must explain spat survival differences over extensive geographical regions to account for the genetic clinal variations observed.

Given substantial gene flow, selection must act to modify the distribution of allele frequencies of barnacle recruits (Nevo et al. 1978, Patarnello et al. 1991, Raimondi 1992, Schmidt \& Rand 1999). In all those studies, high genotype-dependent survival was detected. Our relatively low sample sizes limited the statistical power of our tests. Nevertheless, we observed abrupt variations in allelic frequencies at both $M P I^{*}$ and $G P I^{*}$ loci. Moreover, the changes observed for the $G P I^{*} 2$ are consistent with the population genetic structure of adult barnacles reported by Holm \& Bourget (1994). Indeed, barnacles sampled from a site located south (Saint-Edouard) and transplanted to a site located north (Burnt Church), showed frequencies that were more representative of northern adult barnacles. Conversely, barnacles that remained at a site situated south showed frequencies more representative of barnacles originating south of the Miramichi.

The present isoenzyme results and survival values support the early post-settlement selection hypothesis ( $<5 \mathrm{~d}$, the maximum age of the transplanted individuals). Indeed, in all transplanted populations in which we were able to follow survival for an extended period of time, survival values in populations south of the Miramichi were low $(\bar{x}=36.7 \pm 21.2 \%)$, much lower than north of the Miramichi $(\bar{x}=80.1 \pm 13.8 \%)$, and fully compatible with allele frequency measurements 
obtained. On average, a $10 \%$ change of frequency of GPI was observed in newly settled individuals south of the Miramichi. This population experienced mortality of the order of $65 \%$ within a period of $5 \mathrm{mo}$, the duration of the experiment.

Drouin et al. (2002) examined, also in the Miramichi estuary region, the genotype of newly settled larvae. They found that larvae newly settled on submerged panels from Cap-Lumière (south site) showed allelic frequencies representative of both northern and southern populations. Seasonal changes in patterns of larval distribution also suggest that larvae originating north of the estuary are transported south of the estuary by the spring coastal predominant north-south current. Since the 2 studies were carried out simultaneously and at the same sites, given the temporal distribution of the larvae, it is very likely that our recruits, sampled from SaintEdouard and Cap-Lumière (both south sites), were individuals originating from the larvae having drifted from the region north to the region south of the Miramichi, and the individuals on which natural selection occurred.

Earlier studies (Bourget et al. 1989, Martel 1990, Holm \& Bourget 1994) of Semibalanus balanoides on the east coast of North America have shown the presence of 2 contiguous 'populations'. Based on regional scale studies, Drouin et al. (2002), Dufresne et al. (unpubl.) and our study ( $N_{\mathrm{em}}$ for both loci [MPI and $G P I]$ and both loci in Hardy-Weinberg equilibrium) suggest that barnacles from both sides of the Miramichi estuary represent one population, on which differential selection processes occur.

Selection on GPI and MPI loci have been shown to occur in several species (barnacles: Wethey 1984, Bertness \& Gaines 1993, Schmidt \& Rand 1999; mussels: Levinton \& Lassen 1978, Theisen 1978, Grant et al. 1992; sea anemones: Hoffmann 1981, Ayre 1995; amphipods: Patarnello \& Battaglia 1992). The relationship between fitness and enzyme activity has been discussed in numerous studies (GPI: Krause 1995, Zera 1987; MPI: De La Fuente et al. 1986, Hernandez \& De La Fuente 1988, see also Schmidt \& Rand 1999), and many have related spatial variation in allele frequencies to environmental factors such as temperature (Grant et al. 1992), salinity (Theisen 1978), low oxygen concentration (Shihab \& Heat 1987) and pollution (heavy metals: Lavie \& Nevo 1982, Hvilsom 1983, Nevo et al. 1983, Patarnello et al. 1991; petrochemical agents: Lavie et al. 1984). In our experiments, there is no obvious relationship between temperature and the population structure at the $G P I^{*}$ or $M P I^{*}$ loci. However, our regression analysis showed that salinity seemed to influence the survival of young recruits within the first months of the experiment, but note that significance reached only a $93.5 \%$ level. Indeed, spring outflow of the Miramichi estuary could have an impact on the barnacle spat population located south of the Miramichi by reducing salinity, since circulation patterns in this region favor water transportation north to south. Further work needs to be carried out to examine large scale differences in environmental conditions, and special attention must be placed on microscale factors, i.e. rock temperature and specific rock orientation as a function of waves and shades.

Acknowledgements. We would like to thank L. Lapointe for assistance in the laboratory. Special thanks are due to G. Daigle for statistical assistance. Financial support was provided by NSERC and FCAR to E.B. and by a scholarship from GIROQ (Groupe Interuniversitaire de Recherches Océanographiques du Québec) to A.B. This is a contribution to the program of GIROQ.

\section{LITERATURE CITED}

Ayre D (1995) Localized adaptation of sea anemone clones: evidence from transplantation over two spatial scales. J Anim Ecol 64:186-196

Barnes H (1957) Process of restoration and synchronization in marine ecology. The spring diatom increase and the 'spawning' of the common barnacle Balanus balanoides (L.). Annee Biol 33:67-85

Barnes H, Barnes M (1976) The rate of development of the embryos of Balanus balanoides (L.) from a number of European and American populations and the designation of local races. J Exp Mar Biol Ecol 24:251-269

Benzie JAH, Frusher S, Ballment E (1992) Geographical variation in allozyme frequencies of populations of Penaeus monodon (Crustacea: Decapoda) in Australia. Aust J Mar Freshw Res 43:715-725

Bergeron P, Bourget E (1986) Shore topography and spatial partitioning of crevice refuges by sessile epibenthos in an ice disturbed environment. Mar Ecol Prog Ser 28:129-145

Bertness MD, Gaines SD (1993) Larval dispersal and local adaptation in acorn barnacles. Evolution 47:316-320

Bertness MD, Gaines SD, Bermudez D, Sanford E (1991) Extreme spatial variation in the growth and reproductive output of the acorn barnacle Semibalanus balanoides. Mar Ecol Prog Ser 75:91-100

Bourget E, Martel N, Lapointe L, Bussières D (1989) Behavioural, morphological and genetic changes in some North Atlantic populations of the barnacle Semibalanus balanoides. In: Garbary DJ, South GR (eds) Evolutionary biogeography of the marine algae of the North Atlantic. NATO ASI Series Vol G22, Springer Verlag, Berlin p 87-106

Bousfield EL (1954) The distribution and spawning seasons of barnacles on the Atlantic coast of Canada for the fiscal year 1952-1953. National Museum of Canada, Bulletin No 132, p 112-154

Brown BL, Chapman RW (1991) Gene flow and mitochondrial DNA variation in the killifish, Fundulus heteroclitus. Evolution 45:1147-1161

Burton RS (1983) Protein polymorphisms and genetic differentiation of marine invertebrate populations. Mar Biol Lett 4:193-206

Burton RS, Feldman MW (1982) Population genetics of coastal and estuarine invertebrates: does larval behavior influence population structure? In: Kennedy VS (ed) Estuarine comparisons. Academic Press, New York, p 537-551 
Chabot R, Bourget E (1988) Influence of substratum heterogeneity and settled barnacle density on the settlement of cypris larvae. Mar Biol 97:45-56

Connell JH (1961) Effects of competition, predation by Thais lapillus, and other factors on natural populations of the barnacle Balanus balanoides. Ecol Monog 31:61-104

Connell JH (1985) The consequences of variation in initial settlement vs. postsettlement mortality in rocky intertidal communities. J Exp Mar Biol Ecol 93:11-45

Crisp DJ (1964) Racial differences between North American and European forms of Balanus balanoides. J Mar Biol Assoc UK 44:33-45

Crisp DJ (1968) Differences between North American and European populations of Balanus balanoides revealed by transplantation. J Fish Res Board Can 25:2633-2641

Crisp DJ (1978) Genetic consequences of different reproductive strategies in marine invertebrates. In: Battaglia B, Beardmore JA (eds) Marine organisms: genetics, ecology and evolution. Plenum Press, New York, p 257-273

Dando PR, Southward AJ (1981) Existence of 'Atlantic' and 'Mediterranean' forms of Chthamalus montagui (Crustacea, Cirripedia) in the northern Mediterranean. Mar Biol Lett 2:239-248

De La Fuente M, Penas PF, Sols A (1986) Mechanism of mannose toxicity. Biochem Biophys Res Commun 140: 151-155

Drouin CA, Bourget E, Treublay R (2002) Larval transport processes of barnacle larvae in the vicinity of the interface between tow genetically different populations of semibalanus balanoides. Mar Ecol Prog Ser 229:165-172

Duggins CF Jr, Karlin AA, Mousseau TA, Relyea KG (1995) Analysis of a hybrid zone in Fundulus majalis in a northsouthern Florida ecotone. Heredity 74:117-128

Ford MJ, Mitton JB (1993) Population structure of the pink barnacle, Tetraclita squamosa rubescens, along the California coast. Mol Mar Biol Biotech 2:147-153

Gosselin LA, Qian PY (1996) Early post-settlement mortality of an intertidal barnacle: a critical period for survival. Mar Ecol Prog Ser 135:69-75

Gosselin LA, Qian PY (1997) Juvenile mortality in benthic marine invertebrates. Mar Ecol Prog Ser 146:265-282

Grant WS, Schneider AC, Leslie RW, Cherry MI (1992) Population genetics of the brown mussel Perna perna in southern Africa. J Exp Mar Biol Ecol 165:45-58

Guichard F, Bourget E (1998) Topographic heterogeneity, hydrodynamics, and benthic community structure: a scaledependent cascade. Mar Ecol Prog Ser 171:59-70

Hebert PDN, Beaton MJ (1989) Methodologies for allozyme analysis using cellulose acetate electrophoresis. Helena Laboratories, Beaumont, TX

Hedgecock R (1986) Is gene flow from pelagic larval dispersal important in the adaptation and evolution of marine invertebrates? Bull Mar Sci 39:550-565

Hernandez D, De La Fuente M (1988) Mannose toxicity in Ehrlich ascites tumor. Biochem Cell Biol 67:311-314

Hoffmann RJ (1981) Evolutionary genetics of Metridium senile. I. Kinetic differences in the phosphoglucose isomerase allozymes. Biochem Genet 19:129-144

Holm ER, Bourget E (1994) Selection and population genetic structure of the barnacle Semibalanus balanoides in the north Atlantic and Gulf of St. Lawrence. Mar Ecol Prog Ser 113:247-256

Hunt HL, Scheibling RE (1997) Role of early postsettlement mortality in recruitment of benthic marine invertebrates. Mar Ecol Prog Ser 155:269-301

Hvilsom MM (1983) Copper-induced differential mortality in the mussel Mytilus edulis. Mar Biol 76:291-295
Johannesson K, Kautsky N, Tedengren M (1990) Genotypic and phenotypic differences between Baltic and North Sea populations of Mytilus edulis evaluated through reciprocal transplantations. II. Genetic variation. Mar Ecol Prog Ser 59:211-219

Johannesson K, Johannesson B, Rolan-Alvarez E (1993) Morphological differentiation and genetic cohesiveness over a microenvironmental gradient in the marine snail Littorina saxatilis. Evolution 47:1770-1787

Kautsky N, Johannesson K, Tedengren M (1990) Genotypic and phenotypic differences between Baltic and North Sea populations of Mytilus edulis evaluated through reciprocal transplantations. I. Growth and morphology. Mar Ecol Prog Ser 59:203-210

Koehn RK, Newell RIE, Immermann F (1980) Maintenance of an aminopeptidase allele frequency cline by natural selection. Proc Natl Acad Sci USA 77:5385-5389

Koutitonsky VG, Budgen GL (1991) The physical oceanography of the Gulf of St. Lawrence: a review with emphasis on the synoptic variability of the motion. In: Therriault JL (ed) The Gulf of St. Lawrence: small ocean or big estuary. Can Spec Publ Fish Aquat Sci 113:57-90

Krause MK (1995) The role of Gpi polymorphism in glycolitic flux variations and its effect on genotype dependent viability in the bay scallop. IFREMER, Actes de Colloque No. 17, Cherbourg

Lauzier LM (1965) Drift bottle observations in Northumberland Strait, Gulf of St. Lawrence. J Fish Res Board Can 22: 353-368

Lavie B, Nevo E (1982) Heavy metal selection of phosphoglucose isomerase allozymes in marine gastropods. Mar Biol 71:17-22

Lavie B, Nevo E, Zoller U (1984) Differential viability of phosphoglucose isomerase allozyme genotypes of marine snails in nonionic detergent and crude oil-surfactant mixtures. Env Res 35:270-276

Levinton JS, Lassen HH (1978) Experimental mortality studies and adaptation at the Lap locus in Mytilus edulis. In: Battaglia B, Beardmore JA (eds) Marine organisms: genetics, ecology and evolution. Plenum Press, p 229-254

Littell RC, Henry PR, Ammerman CB (1998) Statistical analysis of repeated measures data using SAS procedures. J Anim Sci 76:1216-1231

Locke A, Courtenay S (1996) Temperature, salinity and water clarity of the Miramichi Estuary, New Brunswick: a comparison of conditions in 1951 and 1992. Can Tech Rep Fish Aquat Sci 2137:1-11

Mallet AL, Haley LE (1983) Growth rate and survival in pure population matings and crosses of the oyster Crassostrea virginica. Can J Fish Aquat Sci 40:948-954

Martel N (1990) Différentiation génétique des cirripèdes (Semibalanus balanoides) du golfe du Saint-Laurent et de la côte atlantique canadienne. MSc thesis, Université Laval, Ste-Foy

McDonald JH (1991) Contrasting amounts of geographical variation as evidence for direct selection: the Mpi and Pgm loci in eight crustacean species. Heredity 67:215-219

McElroy D, Morgan P, Bermingham E, Kornfield I (1991) REAP: an integrated environment for the manipulation and phylogentic analysis of restiction data. J Heredity 83:157-158

Minchinton TE, Scheibling RE (1993) Free space availability and larval substratum selection as determinants of barnacle population structure in a developing rocky intertidal community. Mar Ecol Prog Ser 95:233-244

Milliken GA, Johnson DE (1992) Analysis of messy data. Vol 1, Designed experiments. Van Nostrand Reinhold, New York, p 473 
Mitton JB, Berg CJJr, Orr KS (1989) Population structure, larval dispersal and gene flow in the queen conch, Strombus gigas, of the Caribbean. Biol Bull 177:356-362

Montgomery DC (1991) Design and analysis of experiments. John Wiley \& Sons, Toronto

Nevo E, Shimony T, Libni M (1978) Pollution selection of allozyme polymorphisms in barnacles. Experientia 37: 1152-1154

Nevo E, Lavie B, Ben-Sholmo R (1983) Selection of allelic isozyme polymorphism in marine organisms: pattern, theory, and application. In: Rattazzi MC, Scandalios JG, Whitt GS (eds) Isozyme: current topics in biological and medical research, Vol 10. Alan R. Liss, New York, p 69-92

Nishida M, Lucas JS (1988) Genetic differences between geographic populations of the crown-of thorns starfish throughout the Pacific region. Mar Biol 98:359-368

Ornstein L (1964) Disc electrophoresis. I. Background and theory. Ann NY Acad Sci 121:321-349

Parsons KE (1996) The genetic effects of larval dispersal depend on spatial scale and habitat characteristics. Mar Biol 126:403-414

Patarnello T, Battaglia B (1992) Glucosephosphate isomerase and fitness: effects of temperature on genotype dependent mortality and enzyme activity in two species of the genus Gammarus (Crustacea: Amphipoda). Evolution 46: 1568-1573

Patarnello T, Guinez R, Battaglia B (1991) Effects of pollution on heterozygosity in the barnacle Balanus amphitrite (Cirripedia: Thoracia). Mar Ecol Prog Ser 70:237-243

Pechenik JA, Wendt DE, Jarrett JN (1998) Metamorphosis is not a new beginning. Bioscience 48:901-910

Quesada H, Zapata C, Alvarez G (1995) A multilocus allozyme discontinuity in the mussel Mytilus galloprovincialis: the interaction of ecological and life-history factors. Mar Ecol Prog Ser 116:99-115

Raimondi PT (1988) Rock type affects settlement, recruitment, and zonation of the barnacle Chthamalus anisopoma Pilsbury. J Exp Mar Biol Ecol 123:253-267

Raimondi PT (1992) Adult plasticity and rapid larval evolution in a recently isolated barnacle population. Biol Bull 182: 210-220

Roff DA, Bentzen P (1989) The statistical analysis of mitochondrial DNA polymorphisms: $\chi^{2}$ and the problem of

Editorial responsibility: Otto Kinne (Editor),

Oldendorf/Luhe, Germany small samples. Mol Biol Evol 6:539-545

SAS (1988) SAS/STAT User's guide 6.03 edn. Cary, NC

Scheltema RS (1986) On dispersal and planktonic larvae of benthic invertebrates: an eclectic overview and summary of problems. Bull Mar Sci 39:290-322

Schmidt PS, Rand DM (1999) Intertidal microhabitat and selection at Mpi: interlocus contrats in the northern acorn barnacle, Semibalanus balanoides. Evolution 53:135-146

Shaklee JB, Allendorf FW, Morizot DC, Whitt GS (1990) Gene nomenclature for protein-coding loci in fish. Trans Am Fish Soc 119:2-15

Shihab A, Heat DJ (1987) Components of fitness and Gpi polymorphism, in the freshwater isopod Asellus aquaticus (L.). 2. Zygotic selection. Heredity 58:289-295

SigmaScan Pro (1995). SigmaScan Pro 2.0 edn. Jandel Corporation, San Rafael, CA

SPSS (1999) SPSS for Windows. Version 10.0, Chicago, IL

Strickland JDM, Parsons TR (1968) A practical handbook of seawater analysis. Bull Fish Res Bd Canada 167

Swofford DL, Selander RB (1989) A computer program for the analysis of allelic variation in population genetics and biochemical systematics (Version 1.7). David L. Swofford, Natural History Survey, Urbana, Il

Theisen BF (1978) Allozyme clines and evidence of strong selection in three loci in Mytilus edulis L. (Bivalvia) from Danish waters. Ophelia 17:135-142

Wethey DS (1984) Effects of crowding on fecundity in barnacles: Semibalanus balanoides, Balanus glandula, and Chthalamus dalli. Can J Zool 62:1788-1795

Wethey DS (1986) Local and regional variation in settlement and survival in the littoral barnacle Semibalanus balanoides (L.): patterns and consequences. In: Moore PG, Seed R (eds) The ecology of rocky coasts. Columbia University Press, New York, p 194-202

Williams ST, Benzie JAH (1993) Genetic consequences of long larval life in the starfish Linckia laevigata (Echinodermata: Asteroidea) on the great Barrier Reef. Mar Biol $117: 71-77$

Zar JH (1984) Biostatistical analysis, 2nd edn. Prentice-Hall, Upper Saddle River, NJ, p 718

Zera AJ (1987) Inhibition of phosphoglucose isomerase allozymes from the wing polymorphic waterstrider, Limnoporus canaliculatus, by pentose shunt metabolites. Biochem Genet 23:205-223

Submitted: September 11, 2000; Accepted: August 14, 2001

Proofs received from author(s): February 27, 2002 